GLOBAL JOURNAL OF AGRICULTURAL SCIENCES VOL. 19, 2020: 17- 26

\title{
ASSESSMENT OF GROWTH PERFORMANCE OF AFRICAN CATFISH (Clariasgariepinus) FED WITH FEED PRODUCED FROM BLEND OF PIGEON PEA (Cajanuscajan) BAMBARA GROUNDNUT (Vignasubterranea) AND FISH MEAL
}

ISHIWU, C. N; OPARA A. G; OBIEGBUNA, J. E AND OKEKE, P. A

(Received 4 November 2019; Revision Accepted 9 January 2020)

\begin{abstract}
A 3-factor -factorial experiment $\left(\mathbf{2}^{\mathrm{K}}\right)$ was designed to produce fish feeds from mixture of pigeon pea, bambara groundnut and fish meal as major ingredients, while maize, red palm oil, salt and micro nutrient pre-mix were added as minor ingredients. The raw materials were processed into flours. The ingredients were weighed out in various ratios and mixed. The mixture was extruded; sun-dried and packaged and labeled F1-F8 and a commercial feed labeled F9 served as control. The feeds were feed to juvenile Clariasgariepinus kept in 9 separate plastic bowels and fed for 42 days. The forty-five fish of uniform weight and age were grouped into 9 and stocked in the nine artificial ponds, each pond contained five fish. The feeds were analyzed for proximate composition, while the growth performance of the fish was evaluated at the end of the feeding period. Result showed that F3 $(20 \mathrm{~g}$ pigeon pea, $20 \mathrm{~g}$ Bambara ground nut and $16 \mathrm{~g}$ fish meal) contains the highest protein (33.14 \%) and F1 $(20 \mathrm{~g}$ pigeon pea, $30 \mathrm{~g}$ bambara ground nut and $16 \mathrm{~g}$ fish meal) the least $(23.13 \%)$. F3 exhibited the highest specific growth rate $(1.14 \%)$ followed by the F9 (control) which contains $1.09 \%$. The highest weight gain $(16 \mathrm{~g})$ was observed in the fish fed the control feed. However, F3 and F4 ( $20 \mathrm{~g}$ pigeon pea, $30 \mathrm{~g}$ bambara ground nut and $18 \mathrm{~g}$ fish meal) ranked next to the control with respect to growth performance. It is therefore possible to produce quality catfish feed from bend of pigeon pea, Bambara ground nut and fish meal.
\end{abstract}

\section{KEYWORDS: Catfish, fish feed, bambara groundnut, pigeon pea, fish meal}

\section{INTRODUCTION}

Fish and fish products are known worldwide as very important diet to humans because of their high nutrient quality and significance in improving human health (Amao et al., 2006). Fish is a high-protein, low-fat food that provides a range of health benefits. Fish is lower in fat than any other source of animal protein and oily fish are high in omega-3-fatty acids commonly called "the good fats". Since the human body cannot make significant amount of these essential nutrients, fish consumption becomes an important part of the human diet (Edwin et al., 2001; Oyewole and Amosu, 2012; Uchechukwu et al., 2014). However, in Nigeria the production of catfish looks relatively low compared with the growing population and demand for fish and catfishes of the family Clariidae are the most commonly cultivated fishes(Chris et al., 2011; Adewumi and Oluleye, 2011).It has been reported that the annual fish production in Nigeria is 0.6 million metric tons with a fish demand of 2.66 million metric tons (Adetunji et al.,2009) This implies that fish produced in Nigeria does not meet the demand and that most of the fish consumed in Nigeria are imported. High cost of fish feed, which is also imported has been reported by many researchers to be a major limiting factor in the production of catfish in Nigeria (Ohen and Abang, 2009; Shitote et al., 2011; Nwosu and Onyeneke, 2013),

Researchers have attempted to study the type of feed mostly consumed by Clariasgariepinus. In its range, Clariasgariepinus was found to be omnivorous feeding on plant materials, plankton, anthropods, molluscs,

Ishiwu, C. N., Department of Food Science and Technology, Faculty of Agriculture, Nnamdi, Azikiwe University, Awka-Nigeria

Opara A. G., Department of Food Science and Technology, Faculty of Agriculture, Nnamdi, Azikiwe University, Awka-Nigeria

Obiegbuna, J. E., Department of Food Science and Technology, Faculty of Agriculture, Nnamdi, Azikiwe University, Awka-Nigeria

Okeke, P. A., Department of Fisheries and Aquaculture Technology, Faculty of Agriculture, Nnamdi, Azikiwe University, Awka-Nigeria, 
fishes, reptiles and amphibians (Vitule et al., 2006).

Fishmeal is an excellent protein source in fish feed due to its balanced amino acid profile and high digestibility by fish. Traditionally, fishmeal is the main dietary protein source in fish feed formulation

Pigeon pea (Cajanuscajan) seed is one of the tropical legumes that have been scarcely used in fish feed production in spite of its crude protein and energy profile. Like other leguminous seeds, its nutritive value is masked by the occurrence of anti-nutritional factors, example trypsin inhibitors haemoglutinin and saponin (Francis et al., 2001). According to Adeparusi (1994), Pigeon pea has low human food preference in Nigeria possibly because this pea requires a longer cooking period than cowpea. Pigeon pea is a leguminous plant, it is an annual crop, and it is hardy, widely adaptable and more tolerant of drought and high temperatures than most other crops (Akande et al., 2010). Locally in Nigeria, pigeon pea is called fio-fio by the Igbos, Otili by the Yorubas, Ohete by the Benin and Aduwa or Dan Mata by the Hausas. Pigeon pea is grown extensively in Nigeria but it is still one of the lesser utilized and unexploited legume (Oguntunde, 1985; Enwere, 1998; Nwanna et al., 2008; Alegbeleye et al., 2001l; Ani and Okeke, 2011; Hammed et al., 2013; Orire et al., 2015)

Bambara groundnut (Vignasubterranea) is another underutilized leguminous grain. Its name is derived from the name of a Mali tube called "Bambara". This bean is related to cowpea and it is botanically known as Vignasubterranean (L.) verde, a member of the Fabaceae family (Denis et al., 2015).

In the formulating of fish feed with plant protein sources, caution needs to be observed in their inclusion levels in fish feeds as well as ensuring their proper processing for effective utilization (Francis et al., 2001; Madu et al.,2003). Various treatments such as boiling, toasting and soaking have been used as an effective method of destroying or reducing these antinutritional factors (Salunkhe et al., 1985; Ogunji et al., 2005; Balogun, 2013)

Past works carried out on the use of plant protein as a substitute for fishmeal in fish feed production have been based on the use of a single legume grain combined with fish meal. A few published works that combined various plant raw materials have not tried to determine the main effect of each of the ingredients or the effect of the combined ingredients on the growth performance of the fish.

This present work produced fish feed using two locally sourced legume grains combined with fish meal as major ingredients, while molases, red palm oil, sodium chloride and micro nutrient pre-mix were added as minor ingredients. The produced feeds were evaluated for proximate composition and the growth performance on juvenile catfish (Clariasgariepinus)

\section{MATERIALS AND METHODS \\ Source of Raw Materials}

The ingredients used to formulate the eight (8) experimental feeds that was used in this experiment includes: commercial fishmeal (Danish fish meal), pigeon pea seeds, bambara groundnut seeds, maize seeds, molasses, palm-oil, table salt and vitamin-mineral premix (which consists of 20,000iu, vitamin A, 200 i.u, $\alpha$ tocopherol acetate 400mg, Ascorbic acid 100mg, Vitamin D3, 200mg, Vitamin E, 8mg Vitamin K3, 20mg, Vitamin B1, 30mg, Vitamin B2, 12mg Vitamin B6, 50 mg, Pantothenic acid, $0.8 \mathrm{mg}$, Biotin, $150 \mathrm{mg}$, Niacin, $0.05 \mathrm{mg}$, Niacin, $0.05 \mathrm{mg}$, Vitamin B12, 4.0mg, Cobalt, $40 \mathrm{mg}$, Iron, 5.0mg lodine, 30mg, Manganese, $4 \mathrm{mg}$ Copper, 40 mg, Zinc, 0.2 mg Selenium, 100mg, Lysine, 100mg, Methionine, 100mg, Anti-oxidant were purchased from Nnobi Market, Anambara state. In order to study the performance of the formulated feed, forty five (45) juvenile African catfish (Clariasgariepinus) were stocked in nine plastic bowls (5fish in each). Commercial fish feed was used as the control feed.

\section{Equipment}

Nineartificial pond were constructed. The ponds consisted of nine (9) plastic bowls of equal sizes (50 litres each) which were labeled F1 to F8 and the $9^{\text {th }}$ as control (F9). Water regulatory tap was connected to each bowl to serve as water outlet facility. Mosquito net nailed to planks was used to cover each bowl to prevent foreign matters from entering the pond.

\section{Experimental Design}

The experimental design is a Factorial Design $\left(2^{\mathrm{K}}\right)$, where $\mathrm{k}$ is the No of the factors (Feed ingredients) and 2 = levels of each factor. This was designed using statistical software (MINITAB version 16.0) as shown in Tables $1 \mathrm{a}$ and $1 \mathrm{~b}$ for the design and the ingredient combinations in the runs respectively

Table 1a: Experimental design $\left(2^{\mathrm{K}}\right)$

\begin{tabular}{lcc}
\hline \multicolumn{1}{c}{-1} & +1 & \\
\hline Pigeon pea $(\mathrm{g})$ & & 2030 \\
Bambara ground nut $(\mathrm{g})$ & 20 & 30 \\
Fish meal $(\mathrm{g})$ & 16 & 18 \\
& & \\
\hline
\end{tabular}


Table 1b: The runs with their actual values of the ingredients $(g)$

\begin{tabular}{llll}
\hline Feed & $\begin{array}{l}\text { Pigeon pea } \\
\left(\mathbf{x}_{\mathbf{1}}\right)\end{array}$ & $\begin{array}{l}\text { Bambara groundnut } \\
\left(\mathbf{x}_{\mathbf{2}}\right)\end{array}$ & $\begin{array}{l}\text { Fish meal } \\
\left(\mathbf{x}_{\mathbf{3}}\right)\end{array}$ \\
\hline $\mathbf{1}$ & 20 & 30 & 16 \\
$\mathbf{2}$ & 30 & 20 & 16 \\
$\mathbf{3}$ & 20 & 20 & 16 \\
$\mathbf{4}$ & 20 & 30 & 18 \\
$\mathbf{5}$ & 30 & 30 & 18 \\
$\mathbf{6}$ & 30 & 30 & 16 \\
$\mathbf{7}$ & 20 & 20 & 18 \\
$\mathbf{8}$ & 30 & 20 & 18 \\
\hline
\end{tabular}

\section{Feed Preparation}

The pigeon pea and bambara groundnut seeds were washed and then soaked separately in water at room temperature $\left(28^{0} \mathrm{C} \pm 1\right)$ for 3 days while changing the water every $24 \mathrm{~h}$ in order to avoid fermentation and to reduce the anti-nutrients present in the seeds. After soaking, the seeds were sun dried. The maize grains were cleaned and boiled for 5 minutes to achieve partial gelatinization of the starch which helped the pellet (extruded feed) float on water during the feeding of the fish. All the pre-treated raw materials above were sun dried and milled into very fine particles size (0.6 $\mathrm{mm}$ )using a locally fabricated milling machine. The feed ingredient were weighed out following the combinations in Table $1 \mathrm{~b}$ and each sample was separately prepared by first mixing the dry feed ingredients together, and then separately mixing the wet ingredients $(2 \mathrm{~g}$ molasses, $5 \mathrm{~g}$ red palm oil, $1 \mathrm{~g}$ sodium chloride and $1 \mathrm{~g}$ micro nutrients premix) before combining and mixing all the ingredients together. After mixing, hot water $(5 \%)$ weight of the feed was added to the mixture to form dough. The dough was extruded into feed sizes $(4 \mathrm{~mm})$ using a locally fabricated extruder. The extrudate were sun dried in order to reduce the moisture content for prolonged shelf-life. The dried feeds were packed in bags and labeled as F1, F2, F3, F4, F5, F6, F7 and F8. The control was labeled F9. All the feeds including the control were stored in a dry and airy environment to prevent spoilage. During the feed preparation, the weight of molasses, palm oil, salt and premix were constant in the eight formulated feed samples, while the weight of maize was varied in order to maintain a constant weight for each feed sample at $100 \mathrm{~g}$

\section{Method of Feeding}

The fish were fed two times daily (8am in the morning and $3 \mathrm{pm}$ in the afternoon). Broadcasting method of feeding was used to feed the fish. At every feeding, the fish were fed to satiation and caution was taken not to administer excess feed as this could lead to pollution of the pond which possibly could depletes the dissolved oxygen level of the pond and also wastage of the feed. The pond water was changed every two days or earlier if the pond water became too cloudy. Dirty pond water might lead to suffocation of the fishes and possibly death of the fish

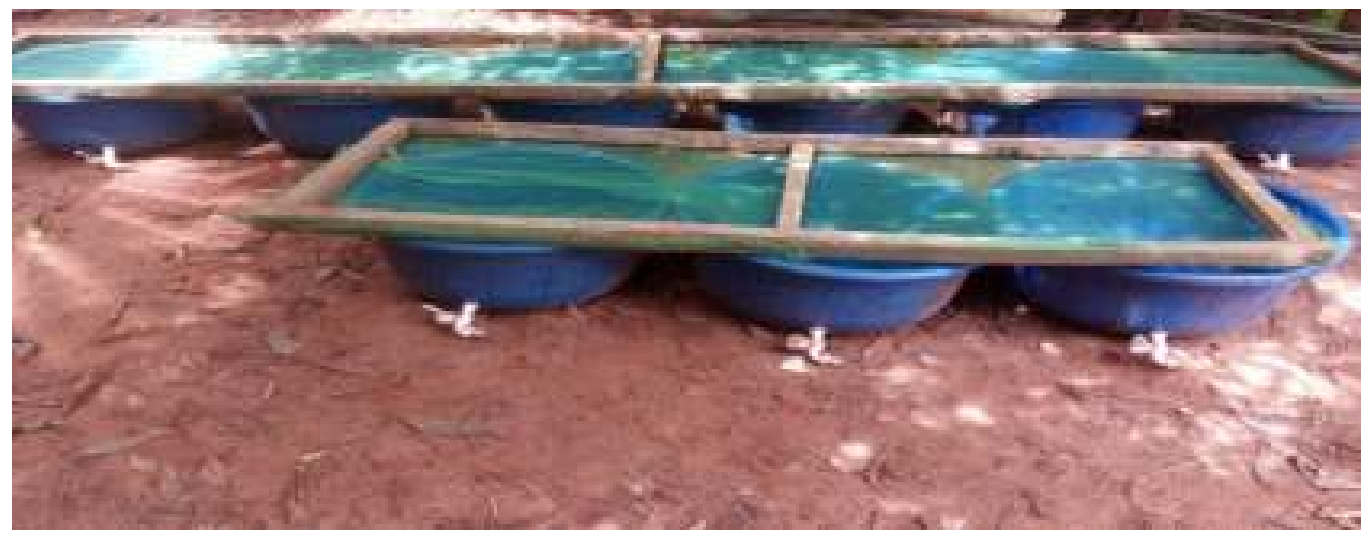

Plate 1: Artificial pond used for the experiment

\section{Proximate Analysis on the formulated feed}

The proximate parameters were analyzed using the Official Methods of Analysis of the Association of Analytical Chemists (AOAC, 2005).

The carbohydrate content of the samples was obtained as the difference between the total summations of percentage moisture, fat, fibre, protein, ash and 100

$\%$ Carbohydrate $=100-(\%$ moisture $+\%$ fat $+\%$ protein $+\%$ fibre $+\%$ ash)

\section{Weight Measurement}

The weight of the individual fish was determined on weekly basis using a digital sensitive weighing balance. A small plastic sieve with handle was used to bring out the fishes singly from the artificial pond for weighing. The fish was starved for 16 hours prior to weighing in order to empty its gut to ascertain the actual weight. 
Weight Gain

The Weight Gain is defined as the average increase in weight of the fish throughout the period of the experiment.

Weight gain $=$ Final weight of the fish at the end of feeding - initial mean weight of the fish before feeding commenced

\section{Specific Growth Rate (SGR)}

Specific Growth Rate is another parameter used in calculating the growth of the fish. It indicates the actual growth of the fishes during the period of the experiment.

\section{Statistical Analysis}

Data generated from the experiment were subjected to statistical analysis using statistical package for Social Sciences (SPSS Version 17.0). Significant differences between means were determined at $P<0.05$. Also SPSS was used to analyse if significant differences exists between the formulated feeds and the control feed. SPSS was also used to determine the significant differences in the weights of fishes fed the different feeds and the control feed.

\section{RESULTS AND DISCUSSIONS Proximate Composition}

The proximate composition of the feeds is shown in figures 5 and 6 . Significant differences $(P<0.05)$ were observed in the proximate composition of the eight formulated feeds and the control. The control contained the smallest amount of moisture $(8.00 \pm 0.00 \%)$ when compared to the other feeds and the difference was significant $(P<0.05)$. This difference could be attributed to the fact that control is a company's product and must have been adequately dried using a dryer instead of sun drying. Feed 8 had the second lowest moisture content $(16.27 \pm 0.38 \%)$ and this value differed significantly $(P<$ 0.05) from the other feeds. Excess moisture could encourage the growth of mould in the stored feed and could result to off flavor development leading to rejection of the feed by the fish. It was also observed that the moisture content of the formulated feeds were high when compared with the control feed. However, the feeds were continuously sun-dried during the experiment to avoid spoilage.

Protein has been reported by earlier researchers to be the most important nutrient in the feed of African catfish. The protein content of a typical fish feed should contain about 25-50 \% protein(Edwin et al., 2001; Hammed et al., 2013). The proximate of some of the formulated feeds fall within the range. Hammed et al. (2013) recommended $25 \%$ inclusion of pigeon pea in fish feed due to its lower protein content when compared to soy bean. Table 3 showed that the formulated feeds had lower protein contents when compared with the control feed. The control feed contained the highest $(40.00 \pm$ $2.00 \%)$ which was significantly different $(P<0.05)$ from the other feeds. F1 was observed to have the lowest protein content $(23.13 \pm 0.18 \%)$ The highest protein content recorded among the eight formulated feeds was found in F3 (33.14\%)

The fat contents of the experimental feeds closely compared with earlier report on fat content of locally produce fish feed (Uchechukwu et al., 2014). It was also observed that feed containing high moisture content had
Specific Growth Rate (SGR) =

$\frac{\left(\mathrm{W}_{2}-\mathrm{W}_{1}\right)}{\text { Period of feeding (days) }} \times \frac{100}{1}$

Where: $W_{2}=$ mean final weight and $W_{1}=$ mean initial weight

\section{Survival Rate}

Survival Rate $(\mathrm{SR})=\underline{\text { final number of fishes }} \times \underline{100}$

Initial number of fish1

low fat content. The highest fat content $(15.27 \pm 0.31 \%)$ was observed in F8. The fat content of the control feed $(11.33 \pm 2.00 \%)$ differed significantly $(P<0.05)$ with the fat content of other feeds. Even though fat is an essential nutrient however, excessive consumption of it could lead to satiety and less feed intake by the fish and this phenomenon could negatively affect the growth and development of the fish. High fat feed if not adequately preserved with antioxidants could easily spoil due to rancidity and consequently the diet would be rejected by the fish when it is administered.

The control feed had the lowest ash content (10.00 \pm $1.00 \%)$ and this value differed significantly $(P<0.05)$ with the ash content of the other feeds. Ash content is an index of the mineral content. This increased ash content suggested that there could be high inclusion of minerals (premix) in the formulated feeds.

The carbohydrates content of the feed ranged between 22.47 and $31.53 \%$. The feed samples showed significant differences in their carbohydrate content $(p<0.05)$ From the feed formulation recipe (Table 3.2), feed 3 had the highest maize content (35\%) this could be responsible for its exhibited higher weight gain and specific growth rate than the other feed counterparts despite its low pigeon pea, bambara nut and fish meal inclusion (16: 20 : 20). This observation corroborates the report of the earlier researcher that high carbohydrate inclusion in catfish feed increased its growth performance even though protein content stands as the most important nutrient in fish feed (Edwin et al., 2001)

The control exhibited the highest crude fiber content $(5.00 \pm 1.00 \%)$ which differed significantly $(P<0.05)$ with the other feeds. Fibre plays important role in animal nutrition even though it does not have calorific value when consumed

\section{Specific Growth Rate (SGR)}

Figure 1 shows that feed 3 had the highest specific growth rate (1.14) followed by the control feed (1.09). Specific growth rate is one of the parameters used in evaluating the growth performance of the fish. It reveals the actual growth of the fishes during the period of the experiment. Feeds 3 and 4 favourably competed with the control in specific growth rate

\section{Weight gain}

Data on the performance of the experimental fishes in terms of their weight gain was presented infigure2. After week one of feeding the fish with the experimental feed, it was observed that there was no significant difference $(P>0.05)$ in the current and initial weights of the fish. This could be that the fishes were not yet fully adapted 
to the new feed or that they consumed less quantity of the feed since they had not been used to the new feed. However, significant increase in weight was achieved in the fishes at the end of the feeding trail. The control exhibited highest weight gain $(16 \mathrm{~g})$ possibly because it is a commercial feed whose quality ought to have been improved over the years through research and development. However, feed $3(15.8 \mathrm{~g})$ ranked next to the control with respect to weight gain

\section{Regression output}

Weight gain versus Pigeon pea, Bambara ground nut, Fish meal

\section{Wt. gain $=-6.5+6.10$ Pigeon pea +3.70 Bambara} ground nut +4.60 Fish meal. Eq.1

From the regression equation the three major components of the feed ( pigeon pea, bambaranut and fish meal) had positive effect on the weight of the fish fed the feed since their regression coefficients were positive. From the regression equation (1) and figure 3, pigeon pea exhibited the highest main effect on the weight gain of the fish followed by fish meal and bambara ground nut showed the least main effect. The main effect of the three major components of the fish feed is presented in figure 3 . The main effect of the feed components (independent variables) are represented by different lines and the length of the line is directly proportional to the main effect that very component had on a given response variable. An ingredient that exhibited longer line has greater effect on the response variable (weight gain) than a component that had a shorter line (Ishiwu et. al., 2015)

From figure 4, it was observed that there was interaction effect between pigeon pea and fish meal on weight gain of the fish, but bambara ground nut has no significant interaction effect with either pigeon pea or fish meal on weight gain of the fish. This suggests that bambara ground nut could be substituted with pigeon pea in the feed recipe without adversely affecting the weight gain of the fish.

\section{Survival Rate (SR)}

The Survival Rate (SR) of the entire fishes during the experimental period of six weeks was $86.67 \%$. The difference $(13.33 \%)$ was mortality rate.

\section{CONCLUSION}

This research has succeeded in producing fish feed from cheap and locally sourced legume grains (pigeon pea and bambara ground nut) and the feed was highly acceptable to juvenile Clariasgariepinus. The feed produced competed favourably well with the most popular commercial fish feed patronized by fish farmers in South East geopolitical zone of Nigeria in proximate composition and growth rate of the fish. Blend of Pigeon pea and fish meal showed interaction effect on weight gain of the fish, while blend of bambara ground nut and fish meal; blend of bambara ground nut and pigeon pea showed no significant interaction effect on weight gain of the fish. The main effect of pigeon pea showed the greatest positive effect on weight gain, followed by fish meal and bambara ground nut. Producers of fish feed are encouraged to utilize both pigeon pea and bambara ground nut in producing fish feed. This practice would promote the use of these locally available but underutilized legume grains.

\section{REFERENCES}

A.O.A.C., 2005. Official Method of Analysis, $17^{\text {th }}$ Edition, Vol. 1 and 2. Horowitz Edition International, Maryland, USA. Washington DC. pp. 452-456.

Adeparusi, E.O., 1994. Evaluation of the Nutritive Potential of Cooked Pigeon pea (Cajanuscajan) Meal as a Plant Protein for Clariasgariepinus Fingerlings. Journal of Agricultural Technology 2 (1): 48-57.

Adetunji, K., Siyanbola, O., Peter, O.A., Diran, O.A., Oluwabunmi, O., 2009. Towards Boosting Aquaculture Production: An Identification of Key Determinants of Catfish (Clariasgariepinus) Consumption in Ibadan Metropolis of Oyo State, Nigeria. Conference on International Research on Food Security, Natural Resource Management and Rural Development. University of Hamburg, October 6 - 8, 2009.

Adewumi, A. A., Olaleye, V. F., 2011. Catfish Culture in Nigeria Progress, Prospects and Problems. African Journal of Agricultural Research. 6 (60):1281-1285.

Akande, K. E., Doma, U. D., Agul, H. O., Adam, H. M., 2010. Major Antinutrients Found in Plant Protein Sources: Their Effect on Nutrition. Pakistan Journal of Nutrition.9 (8):827-832.

Alegbeleye, W. O., Oresegun, A. O., Omitoyin, O., 2001. Use of Bambara Groundnut (Vigna subterranean) meal in the Feeds of Heteroclarias Fingerlings. Moor Journal of Agricultural Research. 2(1):54-59.

Amao, J. O. Oluwatay, I. B., Osuntope, F. K., 2006. Economics of Fish Demands in Lagos State, Nigeria. Journal of Human Ecology.19 (1):25-30.

Ani, A. O., Okeke, G. C., 2010.The Performance of Broiler Birds Fed Varying Levels of Roasted Pigeon pea (Cajanuscajan) Seed Meal. Pakistan Journal of Nutrition. 10 (11): 1036-1040.

Balogun, B. I., 2013. Effects of Processing Method on Anti-Nutrient Levels of Bauliniamonandra Kurzseed. Production Agriculture and Technology Journal. 9 (2): 88-101.

Chris, B., Ndome, A. O., Alfred, A. A., 2011. Effect of Feeding Frequency on Feed Consumption, Growth and Feed Conversion of Clariasgariepinus Hetrobranchuslongifilis Hybrid. American-Eurasian Journal of Scientific Research. 6 (1):06-12.

Denis, N. Y., Kouakou, N. K., Daniela, E., Francesca, S., Nicoletta, P., Maria, C. C., 2015. Nutrition Evaluation of bambara groundnut (Vignasubtaterranea (L) Verde (fabaceae) 
Produced in Cote d'Ivoire Internatio' nal Journal of Molecular Science, 16 (10: 21428-21441

Edwin, H. R, Menghe, H. L., Bruce, B. M., 2001. A Practical Guide to Nutrition Feeds and Feeding of Catfish, Bulletin 113 by the Office of Agricultural Communication, Division of Agriculture, Forestry and Veterinary Medicine, Missisippi State University, U.S. A

Enwere, N.J., 1998. Foods of Plant Origin. Afro-Obis Publications Ltd. Nsukka, pp. 194-199.

Francis, G., Makkar, H.P.S., Becker, K., 2001.Antinutritional Factors Present in Plant Derived Alternative Fish Feed Ingredients and their Effects in Fish. Aquaculture.199 (1):197227.

Hammed, A.M., Amosu, A.O., Fashina-Bombata, H.A., 2013. Effect of Partial and Total Replacement of Soybean Meal with Pigeon pea (Cajanuscajan) as Alternative Plant Protein Source in the Feed of Juveniles African Mud catfish Clariasgariepinus, The Journal of Food Science and Technology.105 (3): 139-145.

Ishiwu, C. N. Obiegbuna, J. E., Igwe, E. C., 2015, Effect of Process Variables on Some Physical Properties and Hydrogen Cyanide Content of Dried Cassava Slices ("Abacha"), Journal of

Food Processing Technology, Vol.6. Issue8, 1000471. http://dx.doi.org/10.4172/2157-7110.1000471

Madu, C.T. Sogbesan, A.O., Iboyo, L.M.O., 2003. Some non-conventional fish feed resources in Nigeria. FAO Research Paper (NSPFJ). 73-82.

Nwanna, L. C. Falaye, A. E., Soolu, A.O., 2008. Water Hyacinth: A Sustainable Protein Source for Fish Feed in Nigeria. Food Health and Environmental Issues in Developing Countries.Alexander Von Humboldt Foundation, Bonn-Germany. Pp. 187194.

Nwosu, C. S., Onyeneke, R. U., 2013. Effect of Productive Inputs of Pond Fish Production on the Output of Fish in Owerri Agricultural Zone of Imo State, Nigeria. Global Advanced Research Journal of Agricultural Science.2 (1): 023-028.
Ogunji, J. O., Uwadiegwu, N., Osuigwe, D. and Wirth, M., 2005.Effects of Different Processing Method of Pigeon pea (Cajanuscajan) on the Haematology of African Catfish (Clariasgariepinus) larvae. Conference on International Agricultural Research for Development. Deuscher Tropentage, 2005. Stuttgart-Hohenheim, October 11-13.

Oguntunde, A., 1985. The Nutritive Value of Boiled Fullfat Soybean in Pelleted Feed for Nile Tilapia. Aquaculture. 81 (7): 303-314.

Ohen, S. B., Abang, S.O., 2009. Economics of Catfish Farming in Rivers State, Nigeria. Academic Journal of Plant Science.2 (1):56-59.

Orire, A. M., Sadiku, S.O.E., Gana, S.N., 2015. Evaluation of Growth Performance and Body Composition of Clariasgariepinus Fingerlings Fed Graded Level of Bambara Nut Meal. Journal of Agriculture and Food

Oyewole, O. E., Amosu, A.M., 2012. Nutritional Considerations and Benefits Associated with Consumption of Catfish in South-West Nigeria. Animal Biological Research. 3 (8): 4094-4098.

Salunkhe, D. K., Chavan, J. K., Kadam, S.S., 1986. Pigeon Pea as Important Food Source. Crit. Rev. Food Science and Nutrition.23(7):103-141.

Shitote, Z., Wakhung, J., China, S., 2011. Challenges Facing Fish Farming Development in Western Kenya. Greener Journal of Agricultural Sciences.3 (5): 305-311.

Uchechukwu, E., Juhami, P., Jouni, V., 2014. Effects of Substitution Soybean (Glycine max) Meal with Bambara Nut Meal on Growth, Performance and Survival of African Catfish (Clariasgariepinus) Larvae. International Journal of Fisheries and Aquatic Studies.1 (3): 152-157.

Van Weerd, J. H., 1995. Nutrition and Growth in Clarias Species - A Review. Aquatic and Living Resources. 8(1): 395-401.

Vitule, J.R.S., Umbria, S.C., Arantia, J.M.R., 2006. Introduction of the African Catfish Clariasgariepinus (Burchell, 1822) into Southern Brazil.Biologicallnvasions8 (4): $\quad$ 677-681. 

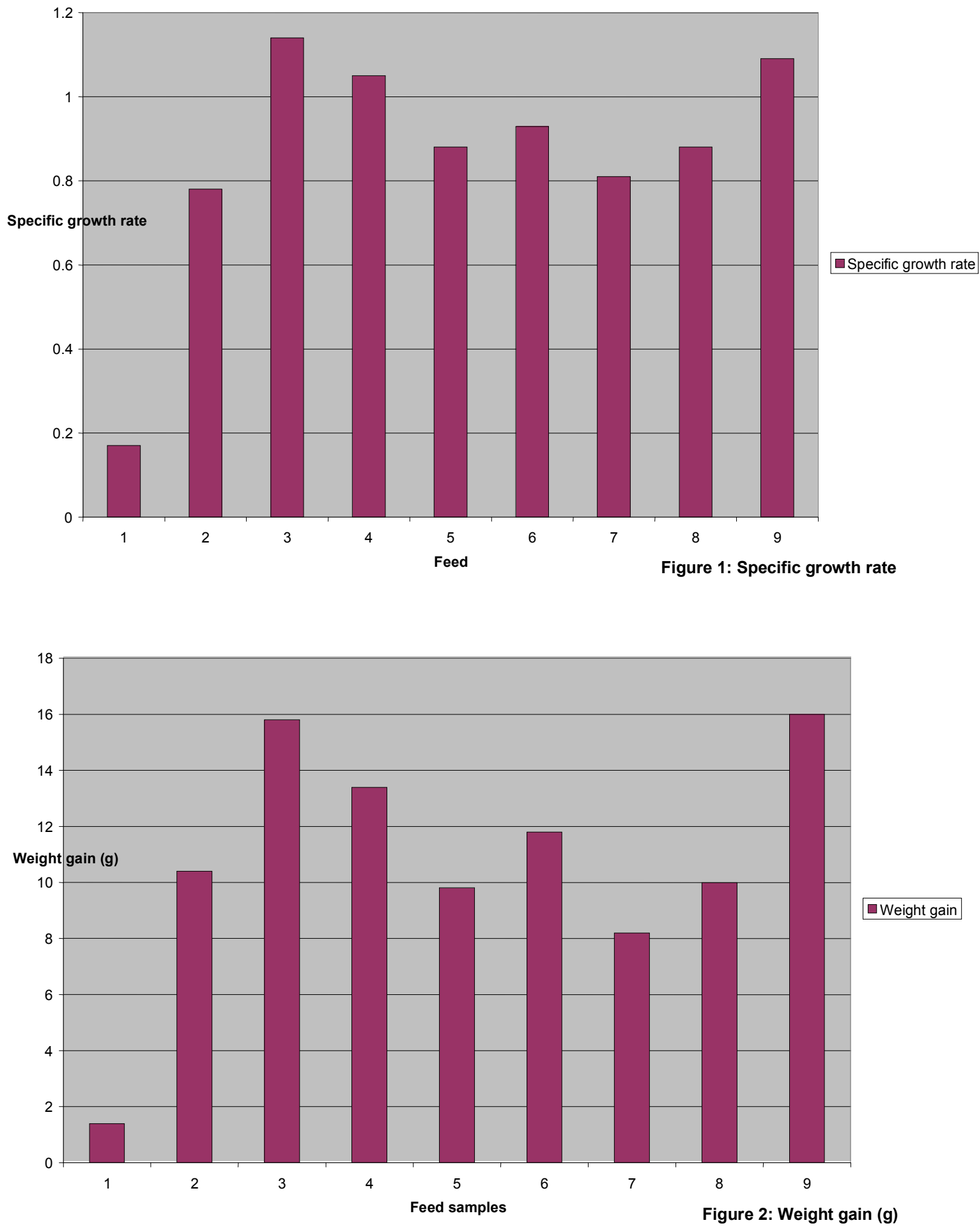

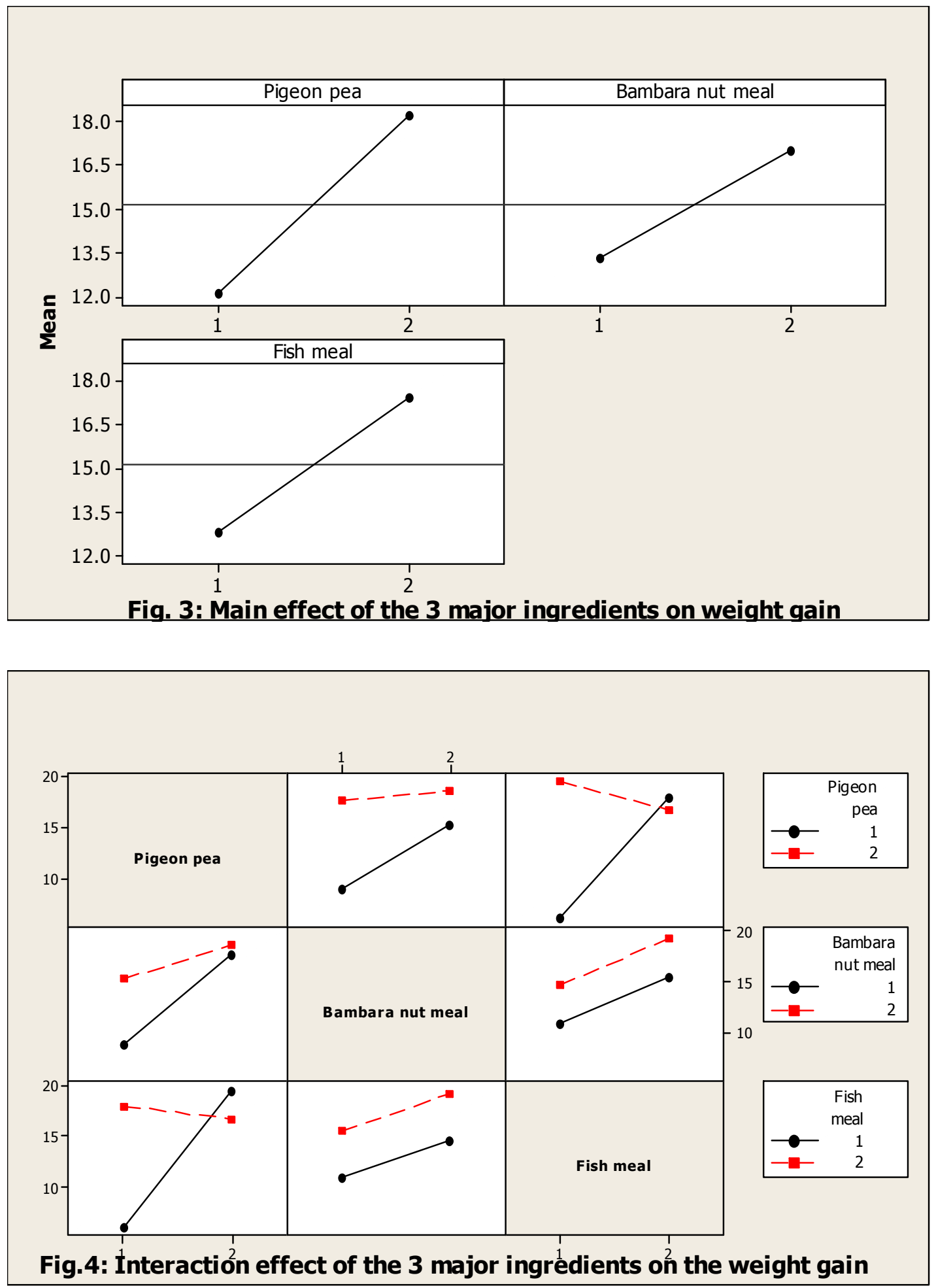


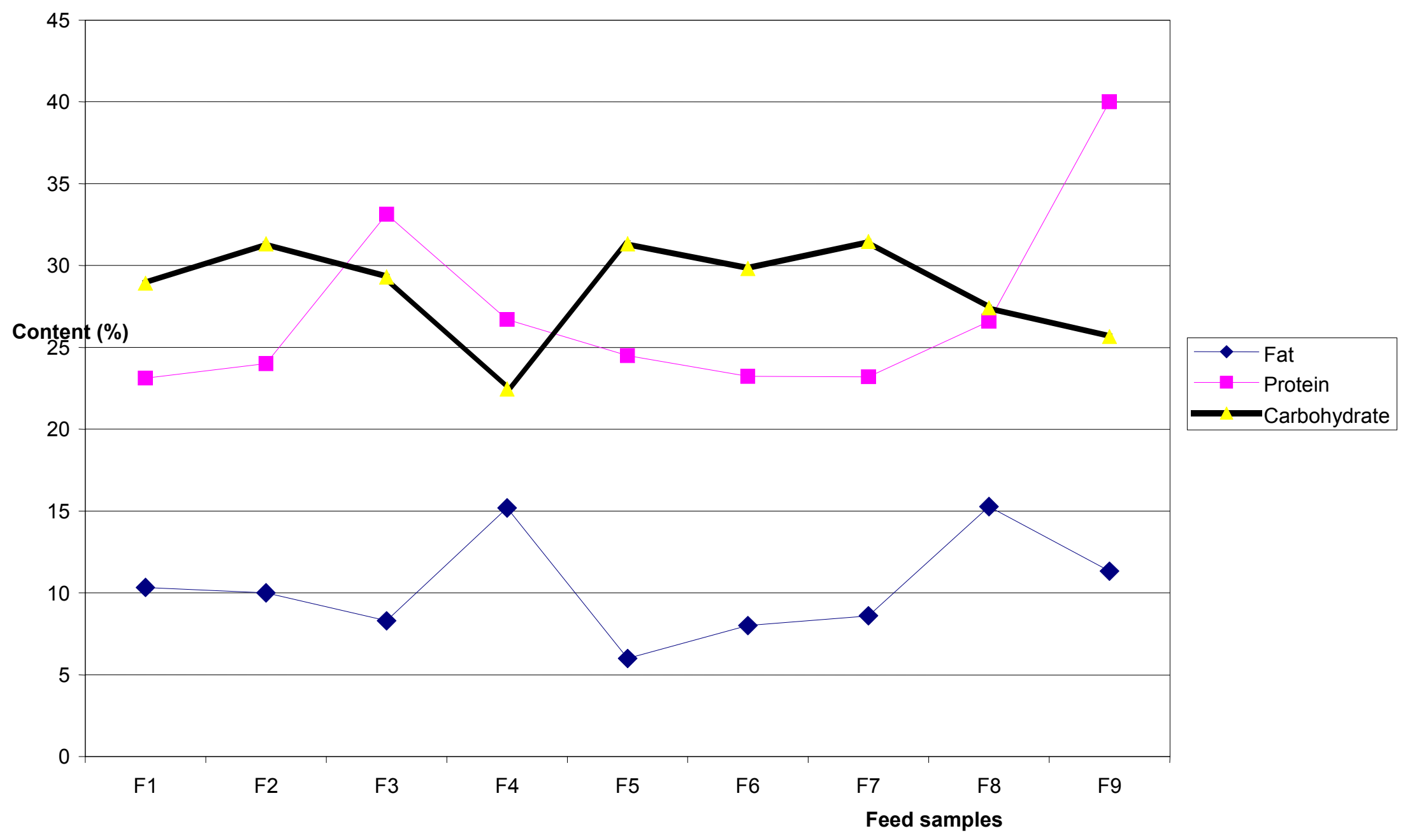

Fig.5: Fat, Protein and Carbohydrate content of the feeds 
ISHIWU, C. N; OPARA A. G; OBIEGBUNA, J. E AND OKEKE, P. A

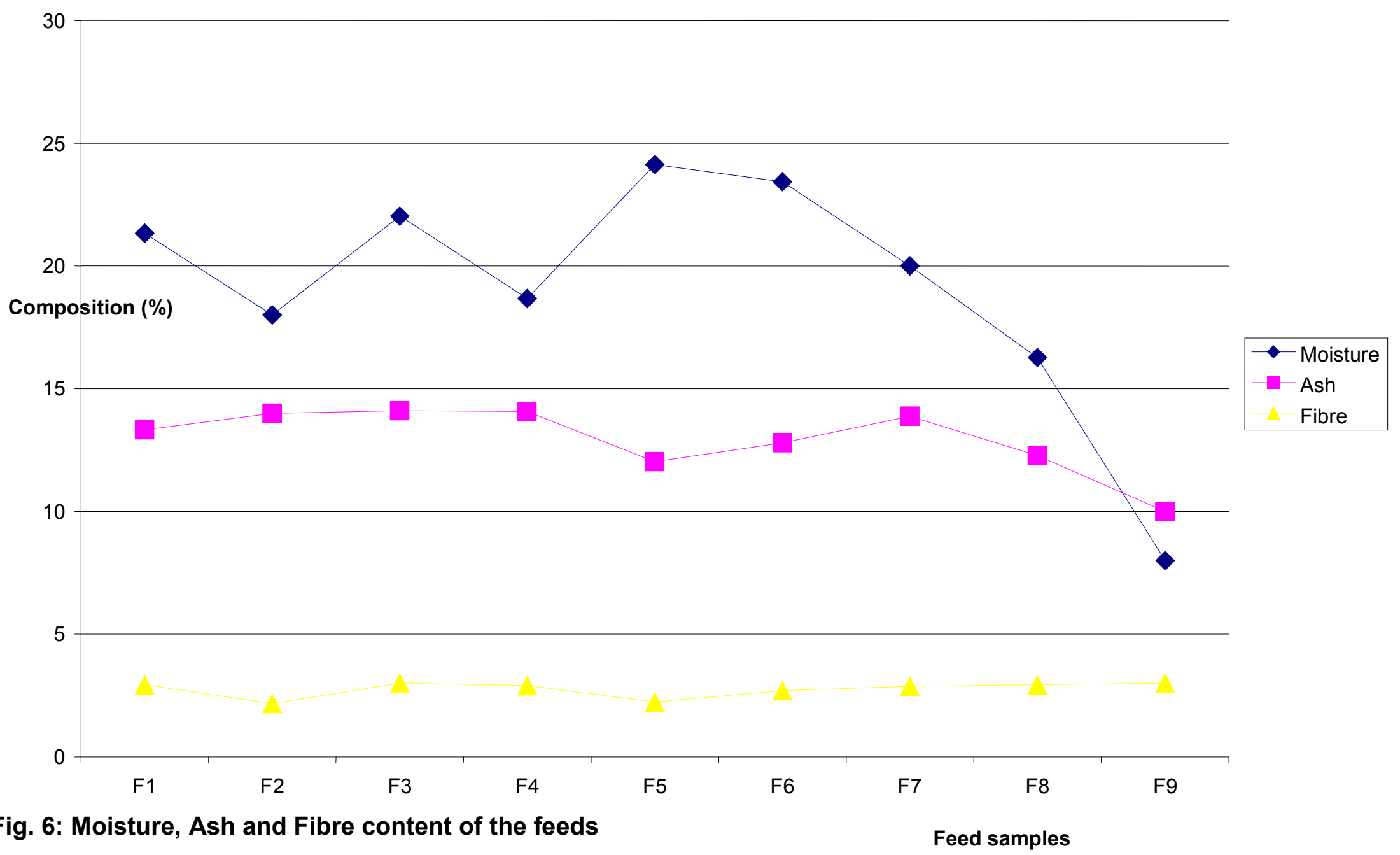

